\title{
Collaboration between Colentina Clinical Hospital and the transplant centers: A chance for life
} Georgeta Daniela GEORGESCU, Felicia MIHAI, Meilin OMER, Viola POPOV, Mihaela ANDREESCU,
Mihaela POPESCU, Oana PATRINOIU, Geanina OFITERU, Marius BALEA, Silvia ION,
Silvia CIORTAN, Claudia DESPAN Hematology Department, Colentina Clinical Hospital, Bucharest, Romania

\begin{abstract}
Background. Stem cell transplantation is an important therapeutic approach for patients with malignant hemopathies, whether we refer to autologous or allogeneic stem cell transplantation.

Aims and methods. We present the characteristics of a group of 54 patients diagnosed with malignant haemopathy in the Department of Hematology of the Colentina Clinical Hospital, between 2004 and 2018, and who have benefited from stem cell transplantation both in the country and abroad. The data analyzed were: diagnosis of the disease, type of response to induction therapy, type and timing of transplantation, transplant in first remission or relapse, if there were patients who benefited from a second transplant, post-transplant survival, as well as demographics.

The statistical analysis was performed using the system MedCalc Statistical Software Version 18.11.3.

Results and conclusions. Survival analysis was applied separately for autotransplant patients and those who benefited from allotransplant (Kaplan Meier survival analyses). Significant differences were observed due to transplantation type and due to relapse after transplant, in our lot of patients. Post-transplant recurrence was an unfavorable prognostic factor for both autologous and allogeneic transplanted patients.

Update. A new challenge: The COVID-19 pandemic threat. The SARS-CoV-2 infection is a threat for immunocompromised patients. From a group of 9 patients hospitalized in 2020 for COVID-19 in the Department of Hematology of the Colentina Clinical Hospital, and who have benefited in the past from stem cell transplantation (2 patients) or organ transplant (1 patient - lung, 3 patients - liver, 3 patients - kidney) in Romania, 4 of them have required hospitalization in the Intensive Care Unit (ICU) (authors's observational data).

New data are needed to elucidate the prognostic factors to establish the outcome of transplant patients such as for all cancer patients or immunocompromised patients in the current COVID pandemic 19 era and the impact on public health.
\end{abstract}

Keywords: transplantation, hemopathies, database, COVID-19

\section{INTRODUCTION}

The first successful hematopoietic stem-cell transplantation was done by Dr. E. Donnall Thomas in late 1950s, for which he received the Nobel Prize in Physiology or Medicine in 1990 [1].
Depending on the type of graft, three procedures are described: syngeneic bone marrow transplantation the donor and the recipient are identical twins; atologous bone marrow transplantation - he bone marrow products are collected from the patient and are reinfused after purification methods; allogenic transplanta- 
tion - the donor is an HLA matched family member, unrelated matched donor or mismatched family donors (haploidentical). [2].

Hematopoietic stem cell transplantation (HSCT) has become the standard of care for many patients with hematologic malignancies but it is also used for patients with solid tumors and nonmalignant disease. multiple myeloma [3], Hodgkin and non-Hodgkin lymphoma [4], acute myeloid leukemia [5], acute lymphoblastic leukemia [6], myelodysplastic syndrome, chronic myeloid leukemia, chronic lymphocytic leukemia, myelofibrosis, essential thrombocytosis, and polycythemia vera [7] and solid tumors [8] are among the indications of stem cell transplantation, along with non-malignant pathologies: aplastic anemia [9], severe combined immune deficiency syndrome [10], thalassemia [11], sickle cell anemia [12] and other nonmalignant diseases [13].

Also it has known over the last two decades rapid growth in use and a constant evolution in its technology which led to the beneficial expansion in applying HSCT to older patients and to those with comorbidities $[14,15]$.

\section{MATERIALS AND METHODS}

Between 2004 and 2018, in the Department of Hematology of the Colentina Clinical Hospital, 54 patients have benefited from stem cell transplantation both in the country and abroad, as it follows: $61.1 \%$ (33/54 patients) underwent autologous stem cell transplantation and $38.9 \%$ (21/54 patients) underwent allogeneic stem-cell transplantation (Fig. 1).

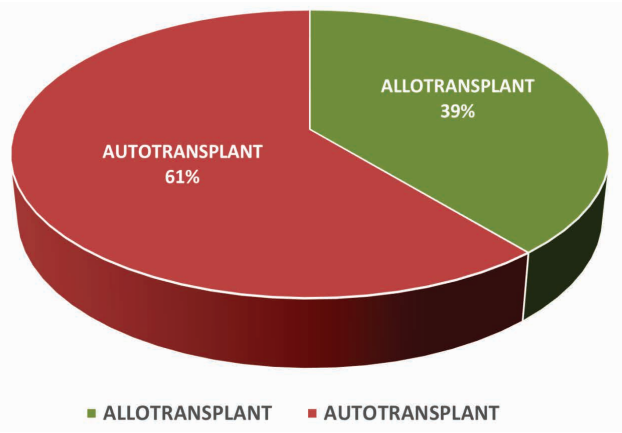

FIGURE 1. Type of transplant

We present the characteristics of a group of 54 patients diagnosed with malignant haemopathy in the Department of Hematology of the Colentina Clinical Hospital, between 2004 and 2018, and who have benefited from stem cell transplantation both in the country and abroad. The data analyzed were: diagnosis of the disease, type of response to induction therapy, pre-transplantation radiotherapy, type and timing of transplantation, transplant in first remission or relapse, if there were patients who benefited from a second transplant, post-transplant survival, as well as demographics.

The statistical analysis was performed using the system MedCalc Statistical Software Version 18.11.3.

Survival analysis was applied separately for autotransplant patients and those who benefited from allotransplant (Kaplan Meier survival analyses).

\section{RESULTS}

The 54 patients studied are between 18 and 65 years of age (average: 41.5 years old); male / female ratio: $25 / 29$. Stem cell transplantation was performed both in the country, at the Center of Bone Marrow Transplantation, Fundeni Clinical Institute, and other Centers from abroad. Transplantation type: autologous: $61.1 \%$ (33/54 patients) and allogeneic: $38.9 \%$ (21/54).

The diagnostics were: acute myeloid leukemia: $20.37 \%$ (11/54); acute lymphoblastic leukemia: $9.25 \%$ (5/54); myelodysplastic syndrome: $1.85 \%$ (1/54); multiple myeloma and plasma cell leukemia: $25.9 \%$ (14/54); Hodgkin lymphoma: 22.2\% (12/54); non-Hodgkin lymphoma: $14.8 \%$ (8/54); adult T-cell leukemia lymphoma: $1.85 \%$ (1/54); myelofibrosis: $1.85 \%$ (1/54); aplastic anemia: $1.85 \%$ (1/54) (fig. 2).

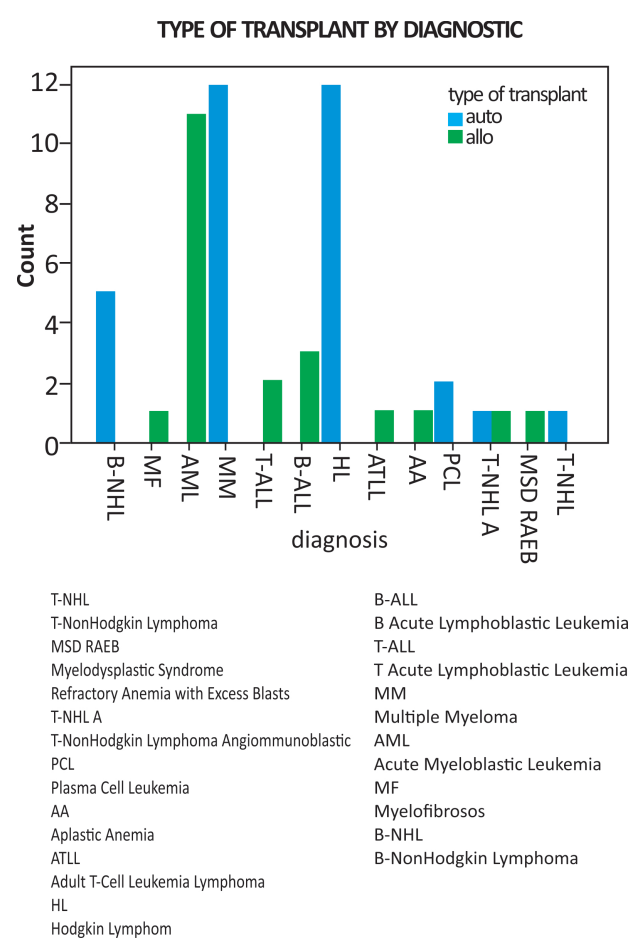

FIGURE 2. Type of transplant by diagnosis

It should be noted that in case of a patient with Hodgkin lymphoma, refractory to chemotherapy plus radiotherapy plus autologous transplantation, with partial remission after Nivolumab therapy, complete 
DISTRIBUTION BY GENDER AND AGE

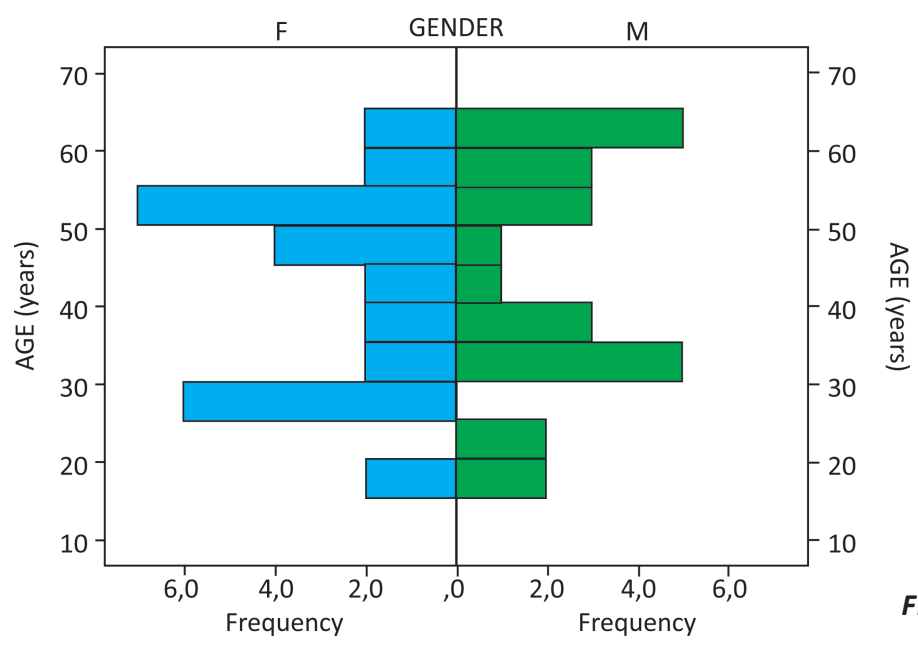

FIGURE 3. Distribution by sex and age

DISTRIBUTION BY TYPE OF TRANSPLANT AND AGE

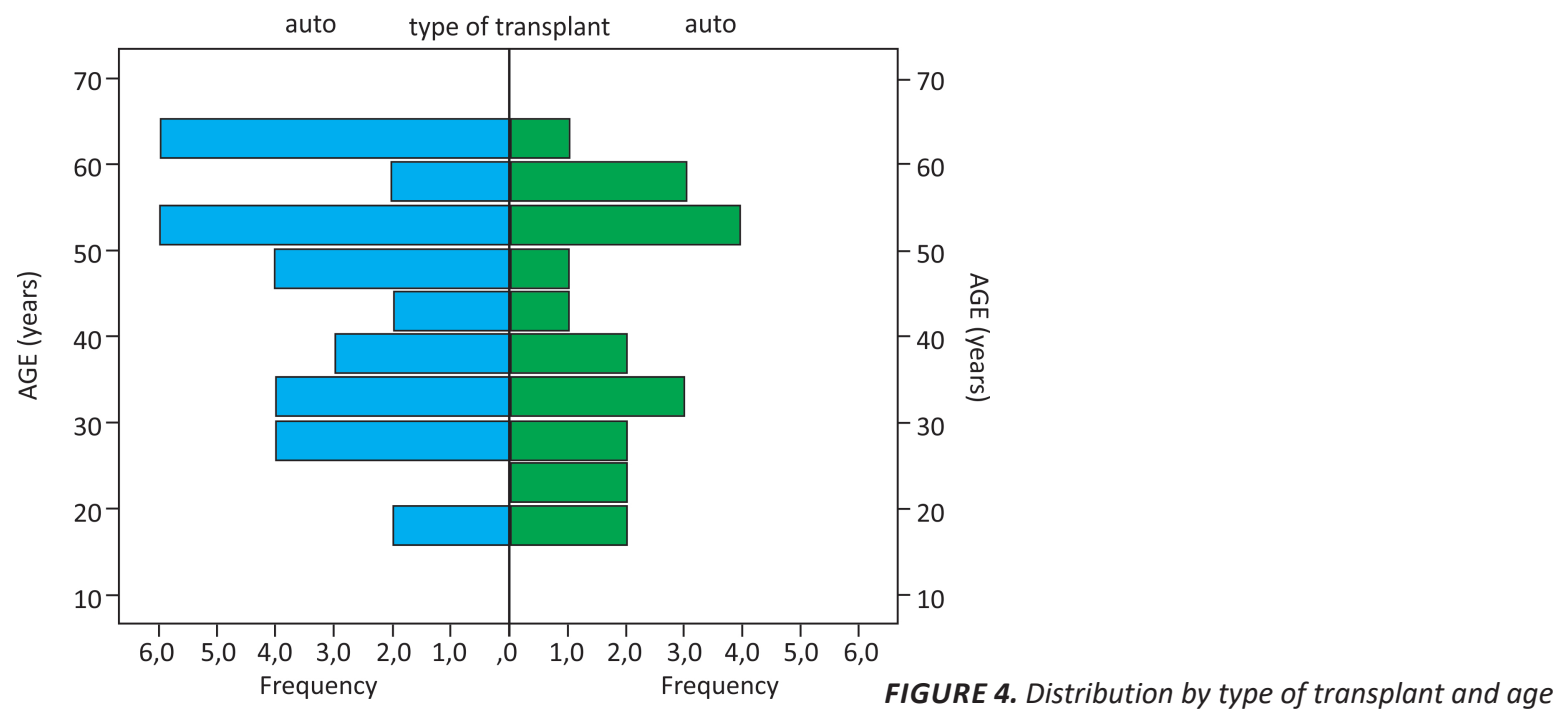

remission was obtained after haploidentical stem cell transplantation (this is the only case that required the second transplant).

In our study the patients are between 18 and 65 years of age (average: 41.5 years old) with a male/female ratio: 25/29 (fig. 3).

The median age for the autologous SCT is 45 years (range: 18-65) and for the allogeneic SCT is 40 years (range: 19-64) (fig. 4).

We retrospectively analyzed the remission status before HSCT and concluded that 39 patients (72\% of cases) were in complete remision before transplantation and in a minority of cases the remission status was partial. In partial remission were mostly patients with a diagnosis of multiple myeloma (fig. 5).

We retrospectively analyzed the data regarding transplant in first remission or relapse, by diagnosis (fig. 6).

We retrospectively analyzed the data regarding relapse after transplant, by type of transplant (fig. 7).
Survival analysis was applied separately for autotransplant patients and those who benefited from allotransplant (Kaplan Meier survival analyses).

The data analyzed were: survival analysis, by type of transplant (Fig. 8), survival analysis, by post transplant relapse (Fig. 9) and survival analysis, by diagnosis: no difference ( $p>0.05$ ) (Fig. 10).

Survival analysis reveals significant differences due to transplantation type and due to relapse after transplant, in our lot of patients. Post-transplant recurrence was an unfavorable prognostic factor for both autologous and allogeneic transplanted patients.

\section{UPDATE: A NEW CHALLENGE: THE COVID-19 PANDEMIC THREAT}

The SARS-COV-2 infection is a threat for immunocompromised patients. From a group of 9 patients hospitalized in 2020 for COVID-19 in the Department of 


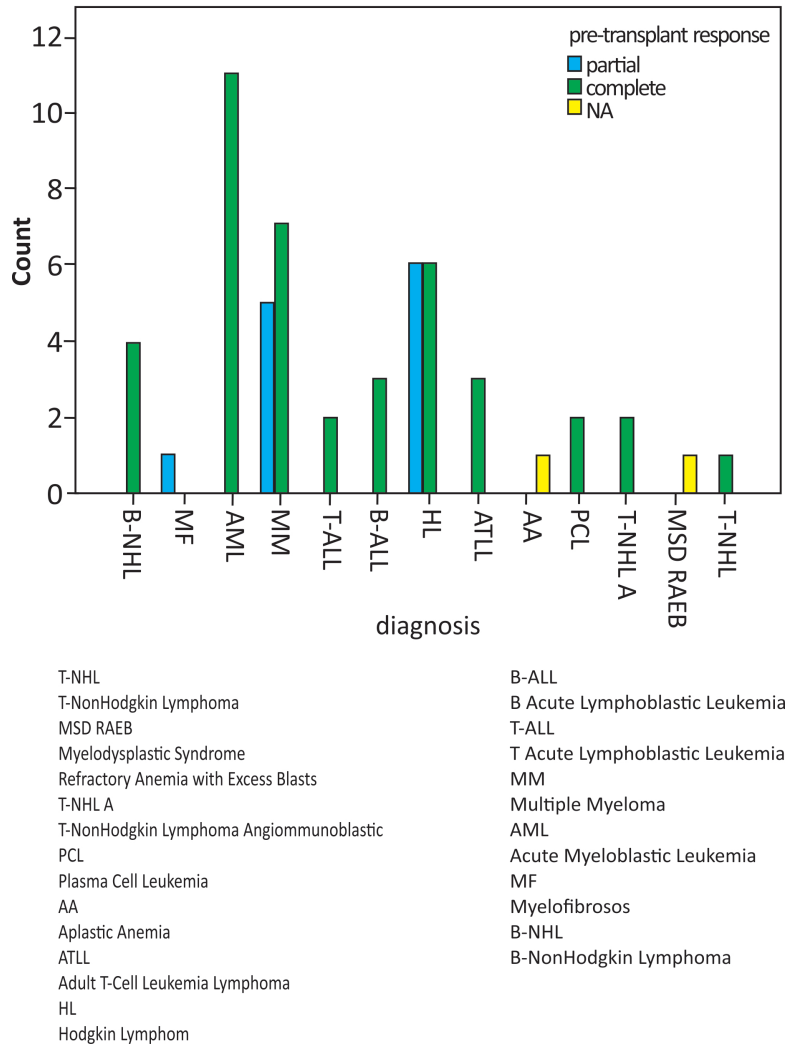

FIGURE 5. Type of response to induction therapy, by diagnosis, before transplant

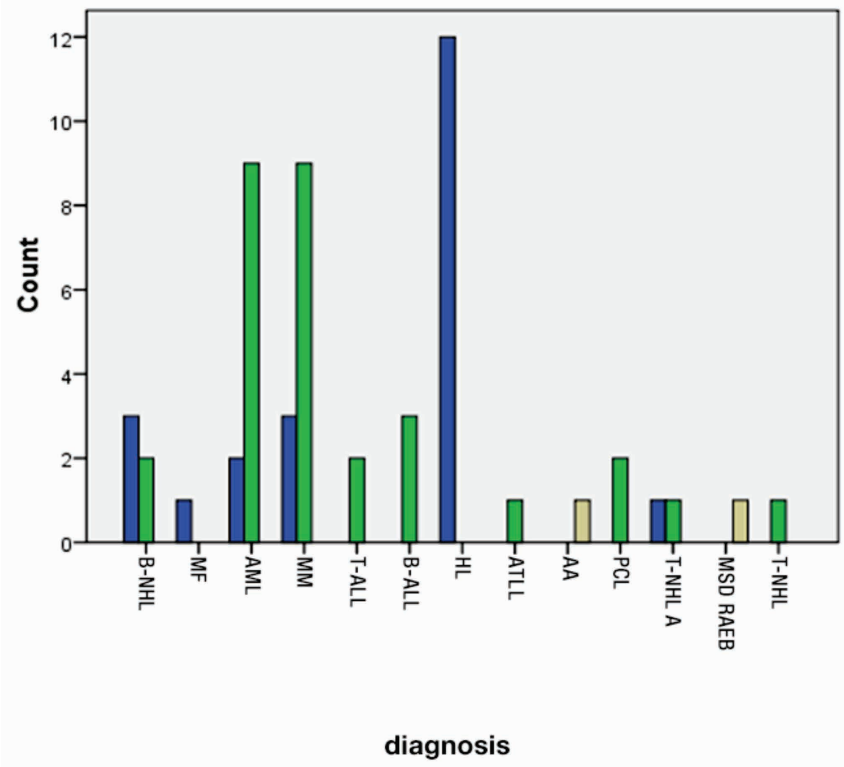

FIGURE 6. Transplant in first remission or relapse, by diagnosis

Hematology of the Colentina Clinical Hospital, and who have benefited in the past from stem cell transplantation (2 patients) or organ transplant (1patient - lung, 3 patients - liver, 3 patients - kidney) in Romania, 4 of them have required hospitalization in the Intensive Care Unit (Table 1).

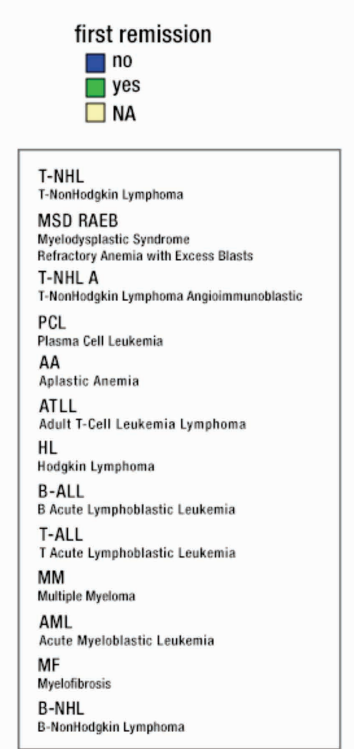

All 4 of them required orotracheal intubation followed by death from complications such as bacterial infections, fungal infections, myocardial infarction. 


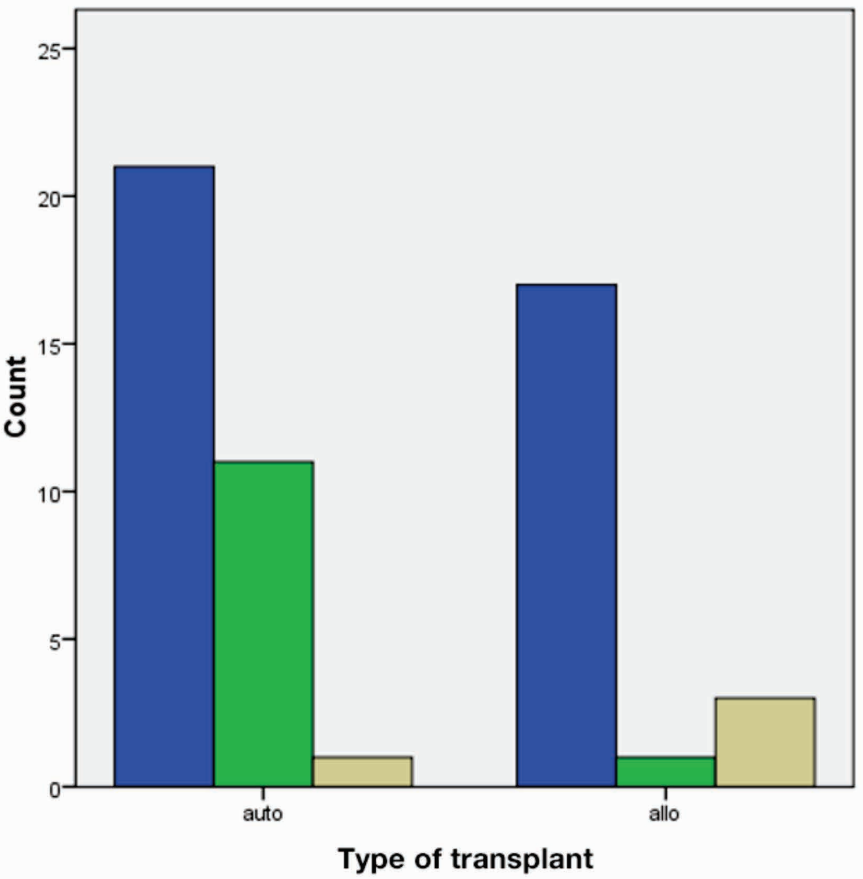

pe of transplant
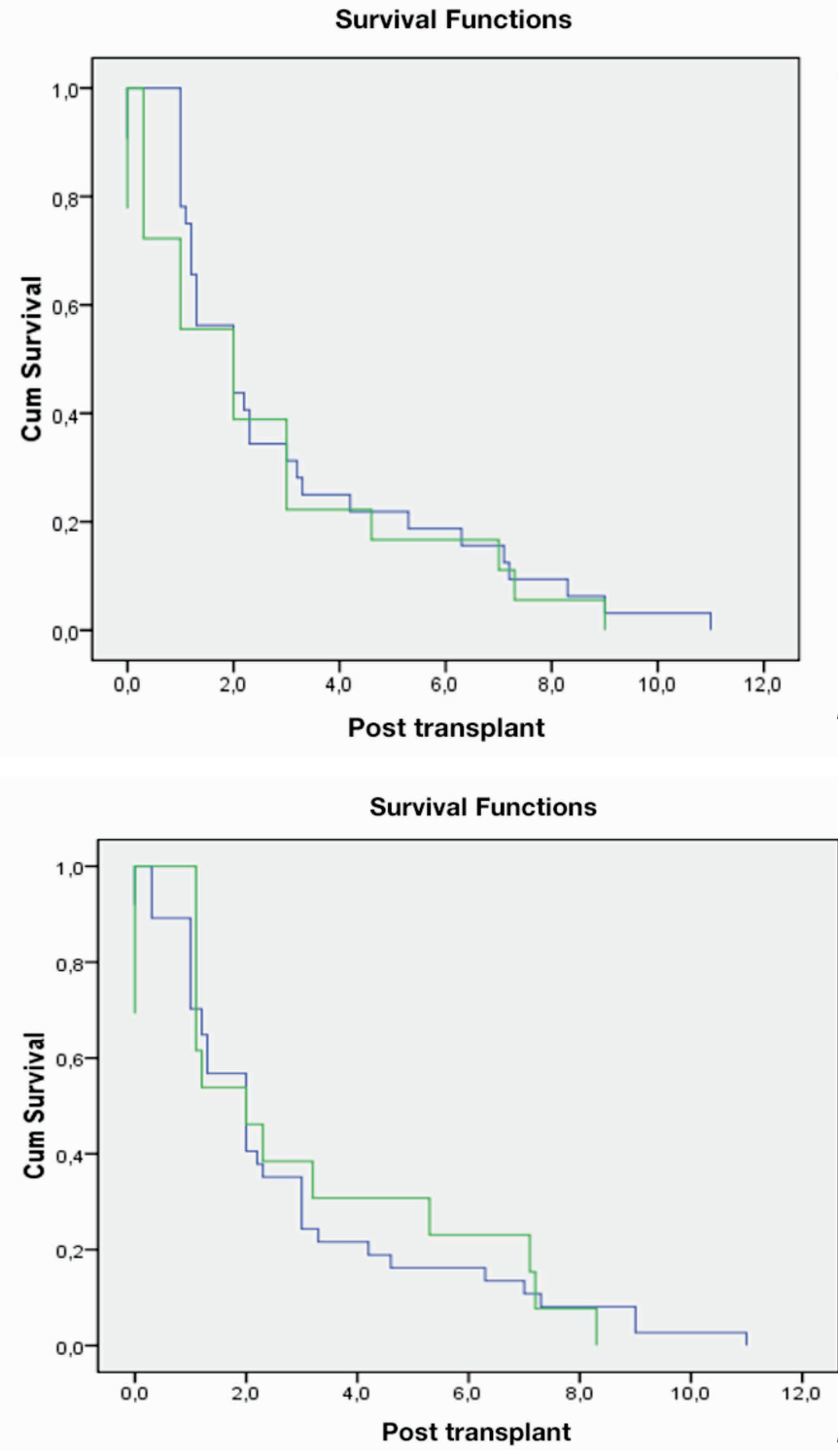

relapse post SCT

(SCT: Stem Cell Transplantation)

$\square$ yes

$\square$ unknown
FIGURE 7. Relapse after transplant, by type of transplant

Type of transplant

$\neg$ auto

$\neg$ allo

FIGURE 8. Survival analysis, by type of transplant

relapse post SCT

(SCT: Stem Cell Transplantation)

$\neg$ no 

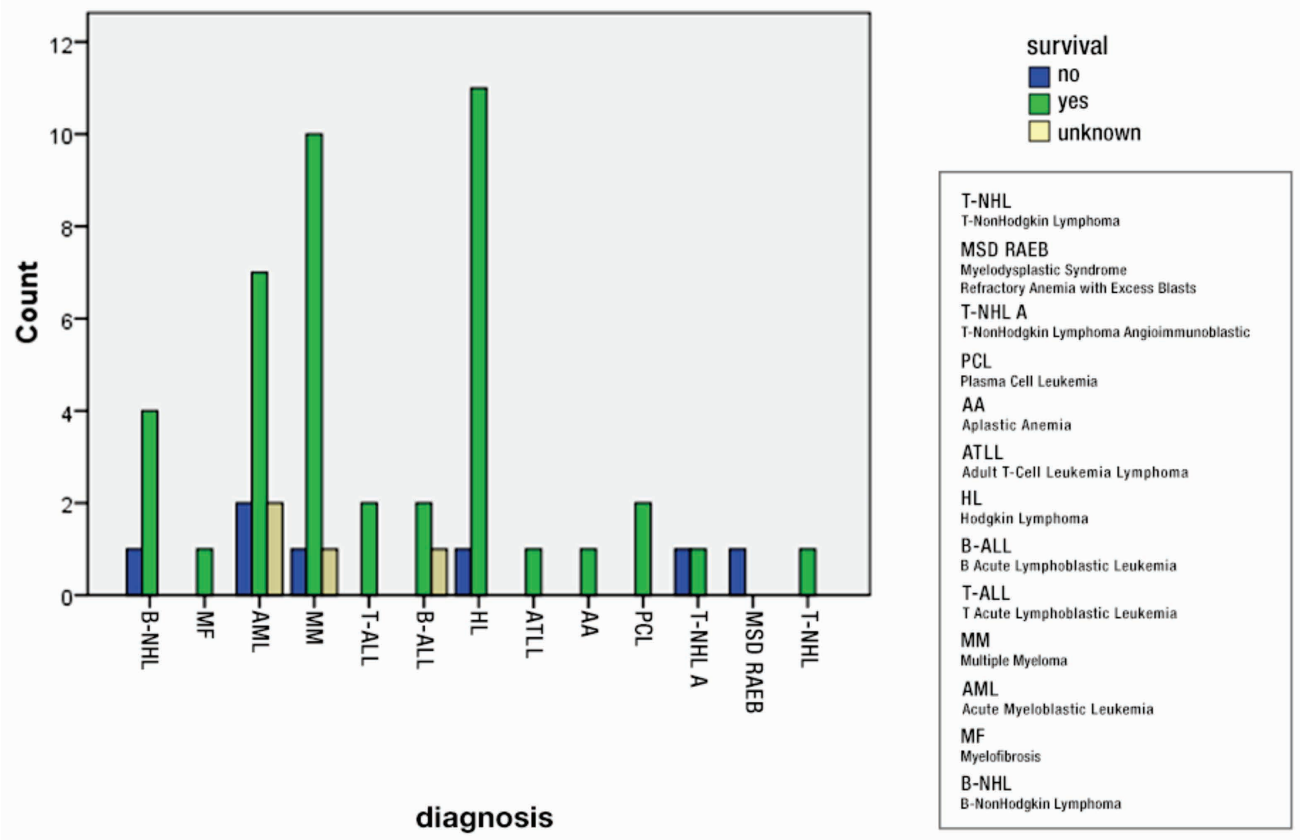

FIGURE 10. Survival analysis, by diagnosis

TABLE 1. COVID-19 Transplant patients

\begin{tabular}{|l|l|l|}
\hline Average (all 9 pts) & Non ICU (5 pts) & ICU (4 pts) \\
\hline $\begin{array}{l}\text { Ly x109/I } \\
0.72(250-2000)\end{array}$ & $1.25(0.26-2 \times 109 / \mathrm{I})$ & $0.33(0.06-0.73 \times 109 / \mathrm{I})$ \\
\hline $\begin{array}{l}\text { Ne/Ly Ratio } \\
29.29\end{array}$ & $9.20(10.23-61.64)$ & $45.30(10.23-80.5)$ \\
\hline $\begin{array}{l}\text { Ferritin } \\
1615 \mathrm{ng} / \mathrm{ml}\end{array}$ & $1183(350-3029 \mathrm{ng} / \mathrm{ml})$ & $2190(840-3725 \mathrm{nd} / \mathrm{ml})$ \\
\hline $\begin{array}{l}\text { II-6 } \\
63.5 \mathrm{pg} / \mathrm{ml}\end{array}$ & $1.5 \mathrm{pg} / \mathrm{ml}$ & $79(142.5-42.5) \mathrm{pg} / \mathrm{ml}$ \\
\hline $\begin{array}{l}\text { CT scan - lung damage } \\
40 \%(10-95 \%)\end{array}$ & $20 \%(10-40 \%)$ & $60 \%(10-95 \%)$ \\
\hline
\end{tabular}

Lymphopenia, elevated neutrophil / lymphocyte ratio, elevated IL-6 levels, elevated ferritin levels were negative prognostic factors, along with a high percentage of lung damage shown on CT scan.

\section{DISCUSSION}

Stem cell transplantation is an important therapeutic approach for patients with malignant hemopathies, whether we refer to autologous or allogeneic stem cell transplantation. According to the guidelines, stem cell transplantation could be indicated in the first line of treatment [16].

In our study, 54 patients have benefited from stem cell transplantation both in the country and abroad, as it follows: $61.1 \%$ (33/54 patients) underwent autologous stem cell transplantation and $38.9 \%$ (21/54 patients) underwent allogeneic stem-cell transplantation. This data is similar to that from a retrospective survey study of patients receiving allogeneic and autologous HSCTs collected in 71 participating countries of the Worldwide Network for Blood and Marrow Transplantation from America, Southeast Asia and the Western Pacific Region, Europe and the Eastern Mediterranean and Africa; in this study allogeneic SCT was performed in $43 \%$ patients and autologous SCT in $57 \%$ patients [14].

From the 33 patients that benefited from autologous stem cell transplantation (SCT), mostly they were with a diagnosis of multiple myeloma (12/33 patients) and Hodgkin lymphoma (12/33 patients). In a majority of cases, from the ones with allogeneic stem-cell transplantation had a diagnosis of acute myeloid leukemia (11/21 patients).

In our study the patients are between 18 and 65 years of age (average: 41.5 years old) with a male / female ratio: $25 / 29$. The median age for the autologous SCT is 45 years (range: 18-65) and for the allogeneic SCT is 40 years (range: 19-64). Majority of autologous 
transplants were done between the ages of 45 and 65 years, meanwhile major indications of allogeneic SCT was in age group less than 40 years. This trend in transplants by type and recipient age is similar to that from a retrospective analysis of first fifty consecutive patients who undergone transplant from a Center in Western India, between 2007 and 2012 [1].

Survival analysis was applied separately for autotransplant patients and those who benefited from allotransplant (Kaplan Meier survival analyses). Significant differences were observed due to transplantation type and due to relapse after transplant, in our lot of patients. Post-transplant recurrence was an unfavorable prognostic factor for both autologous and allogeneic transplanted patients.

Molecular markers in combinations with cytogenetics have improved the risk stratification and quality of decision-making in choosing allogeneic SCT in patients with AML in first complet remission (CR1). In parallel, constant evolution in SCT technology and several important advances in fields such as better supportive care, increased availability of unrelated donors, and reduced-intensity conditioning, have improved the safety as well as access of allo-HCT for a larger number of patients. It is of great importance that early donor identification search should be initiated for all AML patients with transplant eligibility based on risk stratification. In AML intensive chemotherapy used during induction and postremission brings cure rates understandably poor with this approach, and HSCT provides superior outcome for many patients [17].

In our study, all 5 patients with ALL were transplantated in CR1 and 9 out of 11 patients with AML were transplantated in CR1. As for the cases with the diagnosis of non-Hodgkin B-cell lymphoma, 2 cases had autologous HSCT in CR1 and 3 patients had autologous HSCT in CR2. The best results of HSCT in AML, as demonstrated by Thomas and colleagues, occur in patients in first CR [17]. This statement is demonstrated by our study also, as the surviving AML patients who underwent allogeneic SCT represent $63 \%$ of cases.

Autologous stem cell transplantation offers a safe treatment platform, but remain significant concerns regarding relapse [18]. Allogeneic stem cell transplantation has the possibility for cure because of the potential for immunologic graft-versus-disease effect, but nonrelapse mortality remains a significant issue [19].

Analyzing survival by type of transplantation offered to patients in our clinic, we concluded that patients with autologous HSCT can achieve longer survival than patients with allogeneic SCT highlighting the importance of further improvement in disease control and reducing procedure related mortality.

Most of hematopoietic stem cell transplantation cases, in our clinic, were in 2015 , with a total of 11 pa- tients, in 2017, also 11 patients and in 2016, 10 patients. It has known a crescendo pattern in availability and safety from 2004 till present time.

Hematopoietic stem-cell transplantation has improved survival for patients with hematologic malignancies. $80 \%$ of the transplanted patients from the Department of Hematology of the Colentina Clinical Hospital are still alive today.

The SARS-CoV-2 infection is a threat for immunocompromised patients, including transplant patients.

From a group of 9 patients hospitalized in 2020 for COVID-19 in the Department of Hematology of the Colentina Clinical Hospital, and who have benefited in the past from stem cell transplantation ( 2 patients) or organ transplant (1 patient - lung, 3 patients - liver, 3 patients - kidney) in Romania, 4 of them have required hospitalization in the Intensive Care Unit.

Lymphopenia, elevated neutrophil / lymphocyte ratio, elevated IL-6 levels, elevated ferritin levels were negative prognostic factors, along with a high percentage of lung damage shown on CT scan. Our conclusions form preliminary date are similar to those already published [20-23].

\section{CONCLUSIONS}

Stem cell transplantation is an important therapeutic approach for patients with malignant hemopathies, whether we refer to autologous or allogeneic stem cell transplantation. Survival analysis reveals significant differences due to transplantation type and due to relapse after transplant, in our lot of patients. More correlation are being analyzed. Post-transplant recurrence was an unfavorable prognostic factor for both autologous and allogeneic transplanted patients.

The data presented represent a starting point for the establishment of a database / registry to identify the characteristics of patients diagnosed with malignant hemopathies requiring stem cell transplantation and the appropriate time for inclusion in the Stem Cell Transplantation Program, according to the eligibility criteria.

Additional studies and data are needed to elucidate the prognostic factors to establish the outcome of transplant patients such as for all cancer patients or immunocompromised patients in the current COVID-19 pandemic era and the impact on public health.

\section{Acknowledgement}

Georgeta Daniela Georgescu and Claudia Despan are first authors in equal proportion.

Conflict of interest: none declared Financial support: none declared 


\section{REFERENCES}

1. Shah CA, Karanwal A, Desai M, Pandya M, Shah R, Shah R. Hematopoietic stem-cell transplantation in the developing world: experience from a center in Western India. J Oncol. 2015;2015:710543.

2. Khaddour K, Hana CK, Mewawalla P. Hematopoietic Stem Cell Transplantation. 2020 Jun 28. In: StatPearls [Internet]. Treasure Island (FL): StatPearls Publishing; 2021.

3. Palumbo A, Cavallo F, Gay F, Di Raimondo F, Ben Yehuda D, Petrucci MT, et al. Autologous transplantation and maintenance therapy in multiple myeloma. N Engl J Med. 2014 Sep 4;371(10):895-905.

4. Schmitz N, Pfistner B, Sextro M, Sieber M, Carella AM, Haenel M, et al.; German Hodgkin's Lymphoma Study Group; Lymphoma Working Party of the European Group for Blood and Marrow Transplantation. Aggressive conventional chemotherapy compared with high-dose chemotherapy with autologous haemopoietic stem-cell transplantation for relapsed chemosensitive Hodgkin's disease: a randomised trial. Lancet. 2002 Jun 15;359(9323):2065-71.

5. Othus M, Appelbaum FR, Petersdorf SH, Kopecky KJ, Slovak M, Nevill T, et al. Fate of patients with newly diagnosed acute myeloid leukemia who fail primary induction therapy. Biol Blood Marrow Transplant. 2015 Mar;21(3):559-64.

6. Yanada M, Matsuo K, Suzuki T, Naoe T. Allogeneic hematopoietic stem cell transplantation as part of postremission therapy improves survival for adult patients with high-risk acute lymphoblastic leukemia: a metaanalysis. Cancer. 2006 Jun 15;106(12):2657-63.

7. Rondelli D, Goldberg JD, Isola L, Price LS, Shore TB, Boyer M, et al. MPD-RC 101 prospective study of reduced-intensity allogeneic hematopoietic stem cell transplantation in patients with myelofibrosis. Blood. 2014 Aug 14;124(7):1183-91.

8. Einhorn LH, Williams SD, Chamness A, Brames MJ, Perkins SM, Abonour R.
High-dose chemotherapy and stem-cell rescue for metastatic germ-cell tumors. N Engl J Med. 2007 Jul 26;357(4):340-8.

9. Bacigalupo A, Socié $G$, Schrezenmeier $H$, Tichelli A, Locasciulli A, Fuehrer M, et al.; Aplastic Anemia Working Party of the European Group for Blood and Marrow Transplantation (WPSAA-EBMT). Bone marrow versus peripheral blood as the stem cell source for sibling transplants in acquired aplastic anemia: survival advantage for bone marrow in all age groups. Haematologica. 2012 Aug;97(8):1142-8.

10. Pai SY, Logan BR, Griffith LM, Buckley RH, Parrott RE, Dvorak CC, Kapoor N, Hanson IC, et al. Transplantation outcomes for severe combined immunodeficiency, 2000-2009. N Engl J Med. 2014 Jul 31;371(5):434-46.

11. Caocci G, Orofino MG, Vacca A, Piroddi A, Piras $E$, et al. Long-term survival of beta thalassemia major patients treated with hematopoietic stem cell transplantation compared with survival with conventional treatment. Am J Hematol. 2017 Dec;92(12):1303-1310.

12. Angelucci E, Matthes-Martin S, Baronciani D, Bernaudin F, Bonanomi S, Cappellini MD, et al.; EBMT Inborn Error and EBMT Paediatric Working Parties. Hematopoietic stem cell transplantation in thalassemia major and sickle cell disease: indications and management recommendations from an international expert panel. Haematologica. 2014 May;99(5):811-20.

13. Burt RK, Balabanov R, Han X, Sharrack B, Morgan A, Quigley K, et al. Association of nonmyeloablative hematopoietic stem cell transplantation with neurological disability in patients with relapsing-remitting multiple sclerosis. JAMA. 2015 Jan 20; 313(3):275-84.

14. Gratwohl A, Baldomero $H$, Aljurf M, Pasquini MC, Bouzas LF, et al.; Worldwide Network of Blood and Marrow Transplantation. Hematopoietic stem cell transplantation: a global perspective. JAMA. $2010 \mathrm{Apr}$ 28;303(16):1617-24.
15. Majhail NS, Farnia SH, Carpenter PA, Champlin RE, Crawford S, et al. Indications for Autologous and Allogeneic Hematopoietic Cell Transplantation: Guidelines from the American Society for Blood and Marrow Transplantation. Biol Blood Marrow Transplant. 2015 Nov;21(11):1863-1869.

16. Moreau P, San Miguel J, Sonneveld P, Mateos MV, Zamagni E, et al.; ESMO Guidelines Committee. Multiple myeloma: ESMO Clinical Practice Guidelines for diagnosis, treatment and follow-up. Ann Oncol. 2017 Jul 1;28(suppl_4):iv52-iv61.

17. Hamilton BK, Copelan EA. Concise review: the role of hematopoietic stem cell transplantation in the treatment of acute myeloid leukemia. Stem Cells. 2012 Aug;30(8):1581-6.

18. Kuruvilla J. The role of autologous and allogeneic stem cell transplantation in the management of indolent B-cell lymphoma. Blood. 2016 Apr 28;127(17):2093-100.

19. Bensinger WI. Role of autologous and allogeneic stem cell transplantation in myeloma. Leukemia. 2009 Mar;23(3):442-8.

20. Liu J, Liu Y, Xiang P, Pu L, Xiong H, Li C, Zhang M, et al. Neutrophil-to-lymphocyte ratio predicts critical illness patients with 2019 coronavirus disease in the early stage. J Transl Med. 2020 May 20;18(1):206.

21. Tan L, Wang Q, Zhang D, Ding J, Huang Q, Tang YQ, Wang Q, Miao H. Lymphopenia predicts disease severity of COVID-19: a descriptive and predictive study. Signal Transduct Target Ther. 2020 Mar 27;5(1):33.

22. Yang AP, Liu JP, Tao WQ, Li HM. The diagnostic and predictive role of NLR, d-NLR and PLR in COVID-19 patients. Int Immunopharmacol. 2020 Jul;84:106504.

23. Nalbant A, Kaya T, Varim C, Yaylaci S, Tamer A, Cinemre H. Can the neutrophil/ lymphocyte ratio (NLR) have a role in the diagnosis of coronavirus 2019 disease (COVID-19)? Rev Assoc Med Bras (1992). 2020 Jun;66(6):746-751. 